\title{
HUBUNGAN ANTARA PENDIDIKAN DAN PENGETAHUAN IBU BALITA DENGAN POLA PEMBERIAN MP-ASI PADA ANAK USIA 6-24 BULAN DI KELURAHAN KARANG BARU SELAPARANG, MATARAM, NUSA TENGGARA BARAT
}

\author{
Taufiqurrahman, Herta Masthalina, Reni Gatri Wulandari \\ Jurusan Gizi Poltekkes Kemenkes Mataram, Dasan Cermen Cakranegara
}

\begin{abstract}
ABSTRAK
Pemberian MP-ASI yang tidak tepat waktu dan type nya akan beresiko meningkatkan kematian pada balita. Tujuan dari studi ini adalah mengetahui hubungan antara pendidikan dan pengetahuan ibu balita tentang MP-ASI dengan pola pemberian MP-ASI pada anak usia 6-24 bulan. Jenis penelitian ini adalah crosssectional dengan subyek anak usia 6-24 bulan sebanyak 144 orang di Kelurahan Karang Baru, Kecamatan Selaparang, Kota Mataram. Data yang dikumpulkan meliputi karakteristik sampel dan karakteristik ibu balita meliputi umur, pendidikan, dan pekerjaan, serta pengetahuan ibu tentang pola pemberian MP-ASI. Penilaian pola pemberian MP-ASI berdasarkan 3 indikator yaitu pertama kali memberikan, jenis dan frekuensi pemberian MP-ASI. Data diolah menggunakan analisis bivariat dengan uji chi square. Hasil menunjukkan bahwa Ibu balita sebagian besar berumur $20-35$ tahun $(83,3 \%)$ dengan pendidikan sekolah dasar $(48,6 \%)$. Sebagian besar ibu tidak bekerja $(74,3 \%)$, dengan tingkat pengetahuan ibu balita sebagian besar berkategori sedang $(69,4 \%)$. Pola pemberian MP-ASI berdasarkan waktu pertama pemberian MP-ASI sebagian besar $(56,9 \%)$ tidak sesuai karena pemberian MP-ASI yang terlalu dini, namun jika dilihat berdasarkan jenis pemberian MP-ASI, persentase yang tidak sesuai banyak ditemukan pada usia 6-8 bulan $(63,6 \%)$ dan persentase yang sesuai banyak ditemukan pada bayi usia $12-24$ bulan $(70,4 \%)$, sedangkan dari indikator frekuensi pemberian MP-ASI, pada usia 12-24 bulan 100\% balita tidak mendapat MP-ASI yang sesuai anjuran (3-5 kali/hari). Berdasarkan tiga indikator tersebut sebagian besar tidak sesuai pola pemberian MP-ASI $(54,9 \%)$. Analisis bivariat menunjukkan ada hubungan yang signifikan antara pendidikan dengan pola pemberian MP-ASI $(p<0,000)$, demikian juga pada variabel pengetahuan ibu balita $(p<0.000)$.
\end{abstract}

Kata kunci: pendidikan ibu, pengetahuan ibu, dan pola pemberian MP-ASI

\section{ABSTRACT}

\section{THE RELATIONSHIP BETWEEN EDUCATION AND KNOWLEDGE OF MOTHERS TO COMPLEMENTARY FEEDING PRACTICES OF CHILDREN AGED 6-24 MONTHS IN KARANG BARU, SELAPRANG, MATARAM, WEST NUSA TENGGARA}

Giving complementary feeding too early or too late will lead to increase the risk of death in infants.The purpose of the study is to determine the relationship between education and knowledge of women about complementary feeding to its pattern in practice given to children aged 6-24 months. The study was crosssectional and covered 144 children aged 6-24 months in Karang Baru Village, Selaparang District, Mataram. Information gathred were maternal characteristics (age, education, and employment), and maternal knowledge about complementary feeding patterns. The assessment of giving complementary feeding patterns was based on three indicators, namely the first time when complementary food was given, its type and frequency. The data are presented in univariate and bivariate to assess the relationship using chi square test. The results showed that the maternal age ranged $20-35$ years $(83,3 \%)$ with the educational level mostly at primary school $(48.6 \%)$. Most of them did not work $(74.3 \%)$, with the level of complementary feeding knowledge as moderate $(69.4 \%)$. In practice, complementary feeding given for the first time was mostly given too early $(56.9 \%)$. When viewed on the basis of type of complementary feeding, at age of 6-8 months, mostly was not suitable $(63.6 \%)$, but it appropriated at the age of $12-24$ months $(70.4 \%)$. For frequency, all babies were not given appropriately at 12-24 months. In conclusion, most of samples did not appropriate in term of complementary feeding pattern $(54.9 \%)$. A significant relationship was found between education and complementary feeding pattern $(p<0.000)$, as well as maternal knowledge $(p=<0.000)$. In conclusion, there was a relationship between education and knowledge to the complementary feeding patterns.

Keywords: maternal education, maternal knowledge, and complementary feeding practices 


\section{PENDAHULUAN}

$\mathrm{F}$ aktor-faktor penyebab kematian bayi dan balita adalah tingkat ekonomi yang rendah, infeksi/penyakit menular dan lingkungan. Penyebab lain tingginya angka kematian balita adalah pengetahuan ibu tentang perilaku pemberian makanan pendamping ASI (MP-ASI) pada balita yang masih rendah. ${ }^{1}$ Anak- anak yang diberikan makanan pendamping ASI setelah berumur 6 bulan umumnya lebih cerdas dan memiliki daya tahan tubuh lebih kuat, mengurangi risiko terkena alergi akibat makanan. Sedangkan jika makanan pendamping ASI diberikan terlalu dini justru dapat meningkatkan angka kematian bayi, menggangu sistem pencernaan pada bayi, dan apabila terlambat memberikan juga akan membuat bayi kekurangan gizi. ${ }^{2}$ Salah satu penyebab terjadinya gangguan tumbuh kembang bayi dan anak usia 0-24 bulan di Indonesia adalah rendahnya mutu MP-ASI dan tidak sesuainya pola asuh yang diberikan. ${ }^{3}$

Tingkat pengetahuan ibu balita mempengaruhi status gizi balita. Makin tinggi pengetahuan ibu balita, semakin tinggi kesadaran akan perannya dalam keluarga, terutama dalam memperhatikan balitanya. ${ }^{4}$ Penelitian di desa Karang Rejo, kabupaten Kediri, menunjukkan sebagian besar ibu yang memberikan MP-ASI kurang dari 6 bulan memiliki pengetahuan kurang sebanyak 9 responden $(52.9 \%)$ dan ibu yang memberikan MP-ASI setelah 6 bulan memiliki pengetahuan baik sebanyak 10 orang (66.7\%). ${ }^{5}$ Penelitian Wiryo menujukkan, lebih dari 85 persen ibu-ibu di Lombok dan di Jawa Timur memberikan MPASI berupa pisang dan nasi, serta membuang kolostrum. Kalau dikembalikan pada masalah MP-ASI, pemberian MP-ASI dini akan mengakibatkan morbiditas dan mortalitas serta mengurangi keuntungan dan kegunaan ASI Eksklusif. ${ }^{6}$

Hasil penelitian di kelurahan Karang Baru, kecamatan Selaparang, pada bulan Januari tahun 2011 menunjukkan bahwa keberhasilan program ASI Eksklusif mencapai 45 persen, sedangkan 55 persen sudah diberi MP-ASI sebelum usia 6 bulan. Praktek pemberian MPASI dini tersebut lebih tinggi dibandingkan wilayah lain di kota Mataram yang hanya mencapai 30 persen diberikan MP-ASI sebelum usia 6 bulan. $^{7}$ Penelitian bertujuan untuk mengetahui hubungan antara pendidikan dan pengetahuan ibu balita dengan pola pemberian MP-ASI pada anak usia 6-24 bulan.

\section{METODE PENELITIAN}

Penelitian ini merupakan penelitian observasional dengan rancangan potong-lintang (cross-sectional). Populasi penelitian adalah ibu yang mempunyai anak balita usia 6-24 bulan yang bertempat tinggal di kelurahan Karang Baru, kecamatan Selaparang. Pengambilan sampel dilakukan secara systematic random sampling. ${ }^{7}$

Data yang dikumpulkan meliputi data karakteristik sampel anak balita usia 6-24 bulan, yang meliputi jenis kelamin, umur, dan berat badan. Sedangkan data karakteristik responden, meliputi: jenis kelamin, umur, pekerjaan, dan pendidikan ibu balita yang dikumpulkan dengan bantuan formulir identitas/karakteristik dari sampel/responden. Data pengetahuan ibu balita tentang pola pemberian MP-ASI dan data pola pemberian MP-ASI pada anak usia 6-24 bulan, yang meliputi jenis, frekuensi dan waktu pertama pemberian dikumpulkan dengan wawancara dan observasi dengan alat bantu kuesioner.

Pengolahan data karakteristik secara deskriptif, kemudian diklasifikasikan menurut kategori tingkat pendidikan (dasar: 9 tahun, menengah: 10-12 tahun dan tinggi: > 12 tahun). Demikian juga data pola pemberian MP-ASI, yang meliputi indikator waktu pertama pemberian, jenis MP-ASI, dan frekuensi pemberian MP-ASI, dikategorikan berdasarkan dua kategori yaitu sesuai, apabila ketiga indikator pola pemberian MP-ASI dilaksanakan sesuai umur balita dan tidak sesuai, apabila salah satu atau lebih indikator dilaksanakan tidak sesuai umur balita. Sedangkan data pengetahuan responden (ibu balita) diberikan penilaian (scoring) pada setiap pertanyaan, disajikan secara tabulasi dan dianalisis secara deskriptif. Skor total yang diperoleh dikelompokkan ke dalam tingkat pengetahuan berdasarkan nilai rata dan standar deviasi, yaitu baik: $>X+1 S D$, sedang: $X \pm 1 S D$, dan kurang: $<X-1$ SD. 8

Penyajian data setiap variabel secara deskriptif sesuai kategori, dan dianalisis secara univariat sedangkan untuk mengetahui hubungan pendidikan dan pengetahuan dengan 
pola pemberian MP-ASI dilakukan analisis bivariat dengan menggunakan uji chi-square.

\section{HASIL}

\section{Karakteristik Sampel dan Responden}

Sebagian besar sampel berusia 12-24 bulan yaitu 94 anak $(65,3 \%)$. Sampel anak usia 6-24 bulan terdiri dari laki-laki 77 anak $(53,5 \%)$ dan perempuan 67 anak (46,5\%). Berdasarkan karakteristik responden, diperoleh usia responden paling banyak berada pada kelompok usia 20-35 tahun yaitu sebanyak 120 orang $(83,3 \%)$ dan yang terendah pada kelompok usia kurang dari 20 tahun sejumlah 2 orang $(1,4 \%)$. Pendidikan responden terbanyak dalam kategori pendidikan dasar, yaitu 70 orang $(48,6 \%)$, dan yang terendah dalam kategori pendidikan tinggi, yaitu sebanyak 13 orang $(9,0 \%)$. Sebagian besar responden tidak bekerja (sebagai ibu rumah tangga), yaitu sebanyak 107 orang (74,3\%). Untuk lebih jelasnya distribusi karakteristik responden dapat dilihat pada Tabel 1.

Tabel 1

Karakteristik Sampel dan Responden

\begin{tabular}{|c|c|c|c|}
\hline \multicolumn{2}{|c|}{ Karakteristik Sampel dan Responden } & \multirow[t]{2}{*}{$\mathrm{n}$} & \multirow[t]{2}{*}{$\%$} \\
\hline \multicolumn{2}{|l|}{ Karakteristik Sampel } & & \\
\hline \multirow{3}{*}{ Umur Balita (bulan) } & $-6-8$ & 23 & 16,0 \\
\hline & $-\quad 9-11$ & 27 & 18,7 \\
\hline & $-\quad 12-24$ & 94 & 65,3 \\
\hline \multirow[t]{2}{*}{ Jenis kelamin Balita } & - Laki-laki & 77 & 53,5 \\
\hline & - $\quad$ Perempuan & 67 & 46,5 \\
\hline \multicolumn{4}{|c|}{ Karakteristik Responden } \\
\hline \multirow{3}{*}{ Umur lbu (tahun) } & $-\quad<20$ & 2 & 1,4 \\
\hline & $-\quad 20-35$ & 120 & 83,3 \\
\hline & $-\quad>35$ & 22 & 15,3 \\
\hline \multirow[t]{3}{*}{ Pendidikan Ibu } & - Dasar & 70 & 48,6 \\
\hline & - Menengah & 61 & 42,4 \\
\hline & - $\quad$ Tinggi & 13 & 9,0 \\
\hline \multirow[t]{2}{*}{ Pekerjaan Ibu } & - Bekerja & 37 & 25,7 \\
\hline & - Tidak bekerja & 107 & 74,3 \\
\hline
\end{tabular}

\section{Pengetahuan}

Distribusi tingkat pengetahuan ibu tentang pola pemberian MP-ASI diketahui bahwa tingkat pengetahuan responden sebagian besar termasuk dalam kategori sedang, yaitu sebanyak 100 orang $(69,4 \%)$, dan kategori kurang sebanyak 24 orang $(16,7 \%)$.

\section{Pola Pemberian MP-ASI}

a. Waktu Pertama Pemberian MP-ASI berdasarkan Usia Anak

Waktu pemberian MP-ASI merupakan informasi dari gambaran mengenai awal pemberian makanan pendamping selain
ASI. Pemberian makanan tambahan atau MP-ASI seharusnya diberikan pada saat anak balita berusia 6 bulan.

Hasil penelitian menunjukkan bahwa dari 144 anak balita, yang mendapatkan MP-ASI pertama kali sesuai dengan umur pemberian ( $\geq 6$ bulan) yaitu sebanyak 82 anak balita $(56,9 \%)$ dan yang tidak sesuai dengan umurnya sebanyak 62 anak $(43,1 \%)$.

b. Jenis MP-ASI

Jenis makanan pendamping ASI yang dianalisis sebanyak 82 anak, di mana 82 
anak tersebut adalah anak yang mendapatkan MP-ASI pertama yang sesuai pada usia 6 bulan. Untuk melihat jumlah sampel yang mendapatkan MP-ASI berdasarkan jenis yang sesuai dengan usianya dapat dilihat pada Tabel 2 berikut.

Tabel 2

Distribusi Jenis MP-ASI yang diberikan berdasarkan Usia Anak

\begin{tabular}{lcccccc}
\hline \multirow{2}{*}{ Usia (bulan)/jenis } & \multicolumn{2}{c}{ Sesuai } & \multicolumn{2}{c}{ Tidak Sesuai } & \multicolumn{2}{c}{ Total } \\
\cline { 2 - 7 } & $\mathrm{n}$ & $\%$ & $\mathrm{n}$ & $\%$ & $\mathrm{n}$ & $\%$ \\
\hline 6-8/lumat & 7 & 9,9 & 7 & 63,6 & 14 & 17,1 \\
9-11/lunak & 14 & 19,7 & 3 & 27,3 & 17 & 20,7 \\
12-24/padat & 50 & 70,4 & 1 & 9,1 & 51 & 62,2 \\
\hline Total & 71 & 100,0 & 11 & 100,0 & 82 & 100,0 \\
\hline Sumber: Data terolah 2012 & & & & & &
\end{tabular}

Berdasarkan Tabel 2, menunjukkan bahwa diantara subyek penelitian yang berusia 6-8 bulan ternyata sebagian besar mendapatkan jenis MP-ASI yang tidak sesuai usianya yaitu 7 anak $(63,6 \%)$ sedangkan diantara subyek penelitian yang berusia 12-24 bulan, sebagian besar yaitu 50 anak $(70,4 \%)$. mendapatkan jenis MPASI yang sesuai.

\section{c. Frekuensi Pemberian MP-ASI}

Frekuensi pemberian MP-ASI yang dianalisis sebanyak 82 anak, di mana 82 anak tersebut adalah anak yang mendapatkan MP-ASI pertama yang sesuai pada usia 6 bulan. Untuk melihat jumlah sampel yang mendapatkan MP-ASI berdasarkan frekuensi yang sesuai dengan umurnya dapat dilihat pada Tabel 3 berikut.

Tabel 3 menunjukkan bahwa diantara subyek penelitian yang berusia 6-8 bulan, tidak ditemukan subyek yang mendapatkan frekuensi pemberian MP-ASI yang tidak sesuai usianya, sedangkan diantara subyek penelitian yang berusia 12-24 bulan, 100 persen frekuensi pemberian MP-ASI tidak sesuai.

Berdasarkan ketiga indikator pola pemberian MP-ASI yaitu waktu pertama pemberian, jenis dan frekuensi pemberian MP-ASI (Tabel 2 dan Tabel 3) dapat disimpulkan bahwa 54,9 persen, sesuai dengan pola pemberian MP-ASI dan terdapat 45,1 persen yang tidak sesuai dengan pola pemberian MP-ASI.

Tabel 3

Distribusi Frekuensi Pemberian MP-ASI yang Diberikan berdasarkan Usia Anak

\begin{tabular}{lcccccc}
\hline \multirow{2}{*}{ Usia (bulan)/frekuensi } & \multicolumn{2}{c}{ Sesuai } & \multicolumn{2}{c}{ Tidak Sesuai } & \multicolumn{2}{c}{ Total } \\
\cline { 2 - 7 } & $\mathrm{n}$ & $\%$ & $\mathrm{n}$ & $\%$ & $\mathrm{n}$ & $\%$ \\
\hline $6-8 / 2-3 \mathrm{x}$ & 14 & 18,6 & 0 & 0,0 & 14 & 17,1 \\
$9-11 / 2-3 \mathrm{x}$ & 17 & 22,7 & 0 & 0,0 & 17 & 20,7 \\
$12-24 / 3-5 \mathrm{x}$ & 44 & 58,7 & 7 & 100,0 & 51 & 62,2 \\
\hline Total & 75 & 100,0 & 7 & 100,0 & 82 & 100,0 \\
\hline Sumber: Data Terolah 2012 & & & & & &
\end{tabular}




\section{Hubungan antara Pendidikan dengan Pola Pemberian MP-ASI pada Anak Usia 6-24 Bulan}

Tingkat pendidikan yang tinggi, maka pola pemberian MP-ASI akan semakin banyak yang sesuai. Sementara dengan tingkat pendidikan dasar, maka pola pemberian MP-ASI akan semakin sedikit yang sesuai. Untuk lebih jelasnya dapat dilihat pada Tabel 4 .

Tabel 4

Hubungan Pendidikan dengan Pola Pemberian MP-ASI ada Anak Usia 6-24 Bulan

\begin{tabular}{lcccccc}
\hline \multirow{2}{*}{ Kategori Pendidikan } & \multicolumn{3}{c}{ Pola pemberian MP-ASI } & \multicolumn{2}{c}{ Total } \\
\cline { 2 - 5 } & \multicolumn{2}{c}{ Sesuai } & \multicolumn{2}{c}{ Tidak Sesuai } & \multirow{2}{*}{$n$} & $\%$ \\
\cline { 2 - 6 } & $\mathrm{n}$ & $\%$ & $\mathrm{n}$ & $\%$ & & \\
\hline Dasar & 12 & 17,1 & 58 & 82,9 & 70 & 100,0 \\
Menengah & 42 & 68,9 & 19 & 31,1 & 61 & 100,0 \\
Tinggi & 11 & 84,6 & 2 & 15,4 & 13 & 100,0 \\
\hline Total & 65 & 45,1 & 79 & 54,9 & 144 & 100,0 \\
\hline Sumber: Data Terolah 2012 $, \mathrm{p}<0,05$ & & & & &
\end{tabular}

Tabel 4 menunjukkan pola pemberian MP-ASI yang sesuai sebagian besar pada ibu balita yang memiliki pendidikan tinggi, yaitu 84,6 persen, dan sebanyak 17,1 persen pada ibu balita yang memiliki pendidikan dasar. Sementara untuk pola pemberian MP-ASI yang tidak sesuai sebagian besar pada ibu balita yang memiliki pendidikan dasar, yaitu 82,9 persen, dan sebanyak 15,4 persen pada ibu balita yang memiliki pendidikan tinggi.

Hubungan antara Pengetahuan lbu dengan Pola Pemberian MP-ASI pada Anak Usia 6-24 Bulan

Pemberian makanan pendamping ASI (MP-ASI) berjalan baik maka diperlukan pengetahuan dan perilaku yang baik pula mengenai MP-ASI, dan salah satu faktor intern yang mempengaruhi terbentuknya perilaku manusia adalah pengetahuan. Hubungan pengetahuan ibu balita dengan pola pemberian MP-ASI dapat dilihat pada Tabel 5.

Berdasarkan Tabel 5, dapat dilihat bahwa pola pemberian MP-ASI yang sesuai sebagian besar pada ibu balita yang memiliki pengetahuan baik, yaitu 75,0 persen, dan sebanyak 4,2 persen pada ibu balita yang memiliki pengetahuan kurang. Sementara untuk pola pemberian MP-ASI yang tidak sesuai sebagian besar pada ibu balita yang memiliki pengetahuan kurang, yaitu 95,8 persen, dan sebanyak 25,0 persen pada ibu balita yang memiliki pengetahuan baik.

Tabel 5

Hubunga Pengetahuan Ibu dengan Pola Pemberian MP-ASI pada Anak 6-24 Bulan

\begin{tabular}{lcccccc}
\hline \multirow{2}{*}{$\begin{array}{l}\text { Kategori } \\
\text { Pengetahuan }\end{array}$} & \multicolumn{3}{c}{ Pola pemberian MP-ASI } & \multicolumn{2}{c}{ Total } \\
\cline { 2 - 5 } & \multicolumn{2}{c}{ Sesuai } & \multicolumn{2}{c}{ Tidak sesuai } & & \multirow{2}{*}{$\mathrm{n}$} \\
\cline { 2 - 6 } & $\mathrm{n}$ & $\%$ & $\mathrm{n}$ & $\%$ & & \\
\hline Baik & 15 & 75,0 & 5 & 25,0 & 20 & 100,0 \\
Sedang & 49 & 49,0 & 51 & 51,0 & 100 & 100,0 \\
Kurang & 1 & 4,2 & 23 & 95,8 & 24 & 100,0 \\
\hline Total & 65 & 45,1 & 79 & 54,9 & 144 & 100,0 \\
\hline
\end{tabular}




\section{BAHASAN}

\section{Waktu Pertama Pemberian MP-ASI Berdasarkan Usia Anak}

Waktu pemberian MP-ASI merupakan informasi dari gambaran mengenai awal pemberian makanan pendamping selain $\mathrm{ASI}$, di mana pemberian makanan tambahan atau MPASI seharusnya diberikan pada saat anak balita berusia 6 bulan. Hasil penelitian dari 144 anak balita, yang mendapatkan MP-ASI pertama kali sesuai dengan umur pemberian ( $\geq 6$ bulan) yaitu sebanyak 56,9 persen. Pola ini cukup baik karena sesudah usia bayi 6 bulan pemberian ASI saja tidak lagi dapat memberikan cukup energi serta zat gizi untuk meningkatkan tumbuh kembang anak secara optimal, dan makanan lengkap (MP-ASI) harus ditambahkan dalam makanan anak tersebut. ${ }^{12}$ Pola pemberian MP-ASI yang tidak sesuai dengan umurnya sebanyak 43,1 persen. Hal ini menunjukkan masih banyak ibu yang memberikan makanan tambahan pada balita yang berusia kurang dari 6 bulan. Penyebabnya adalah kurangnya pengetahuan ibu, kurangnya informasi yang didapatkan, kesibukan ibu, adat istiadat serta masalah/gangguan dalam produksi ASI. Dengan pemberian makanan tambahan yang terlalu dini dapat menimbulkan gangguan saluran pencernaan sehingga mudah terserang diare.

\section{Jenis MP-ASI}

Jenis makanan pendamping ASI yang dianalisis sebanyak 82 anak, di mana 82 anak tersebut adalah anak yang mendapatkan MPASI pertama yang sesuai pada usia 6 bulan. Berdasarkan hasil wawancara, hal ini disebabkan karena kurangnya pengetahuan dan informasi yang didapatkan ibu balita mengenai jenis makanan yang harus diberikan sesuai usia anak. Dan para ibu sudah banyak yang memperkenalkan makanan keluarga kepada anak balita sejak usia 1 tahun (12 bulan) dengan bentuk makanan yang diberikan adalah makanan padat.

\section{Frekuensi Pemberian MP-ASI}

Frekuensi pemberian MP-ASI yang dianalisis sebanyak 82 anak, di mana 82 anak tersebut adalah anak yang mendapatkan MPASI pertama yang sesuai pada usia 6 bulan, dari 82 orang sampel yang terbanyak mendapatkan frekuensi pemberian MP-ASI yang sesuai usianya adalah anak yang berusia 12-24 tahun dengan jumlah 44 anak $(58,7 \%)$ dan yang tidak sesuai terbanyak pada usia 1224 bulan bulan, yaitu 7 anak $(100,0)$. Frekuensi pemberian makan pada anak balita sudah dapat dikatakan bagus, karena hanya 7 orang anak balita yang tidak sesuai, hal ini disebabkan karena para ibu sudah mengetahui seharusnya berapa kali anaknya makan dalam sehari. Sehingga anak balita terbiasa makan sesuai dengan jadwal yaitu pagi, siang dan malam.

Responden yang tidak sesuai disebabkan karena keterbatasan bahan pangan di keluarga sehingga frekuensi pemberian MP-ASI pada anak dibatasi pula. Dan dari hasil beberapa penelitian menyatakan bahwa keadaan kurang gizi pada bayilanak disebabkan karena kebiasaan pemberian MP-ASI yang tidak tepat. ${ }^{1}$

Hasil identifikasi hasil penelitian berdasarkan pola pemberian MP-ASI (waktu pertama pemberian, jenis dan frekuensi pemberian MP-ASI) diketahui bahwa dari 144 sampel terdapat 79 anak balita yang tidak sesuai dengan pola pemberian MP-ASI dan terdapat 65 yang sesuai dengan pola pemberian MP-ASI. Hal ini disebabkan karena pendidikan ibu balita yang sebagian besar termasuk dalam kategori dasar serta kurangnya pengetahuan ibu balita tentang pola pemberian MP-ASI terutama pengetahuan mengenai waktu pertama pemberian MP-ASI dan jenis pemberian MP-ASI yang harus diberikan sesuai dengan usia anak, sehingga banyak ibu balita yang memberikan makanan kepada anaknya tanpa mengetahui apakah makanan yang diberikan tersebut sesuai dengan usia anak.

\section{Hubungan Antara Pendidikan Dengan Pola Pemberian MP-ASI Pada Anak Usia 6-24 Bulan}

Pola pemberian MP-ASI yang tidak sesuai sebagian besar pada ibu balita yang memiliki pendidikan dasar, yaitu 82,9 persen, dan sebanyak 15,4 persen pada ibu balita yang memiliki pendidikan tinggi. Hal ini menunjukkan, bahwa semakin tinggi pendidikan seseorang maka pola pemberian MP-ASI pada anak balita akan cenderung semakin baik. Berdasarkan uji statistik menggunakan uji chi-square didapatkan nilai probabilitas $=0,000(p<0,05)$ yang berarti ada hubungan yang signifikan antara 
pendidikan ibu dengan pola pemberian MP-ASI. Hasil tersebut juga dikuatkan oleh Nuraeni, yang mengatakan bahwa tingkat pendidikan orang tua berhubungan dengan pola pemberian MP-ASI. ${ }^{10}$ Sependapat juga dengan hasil penelitian Rita bahwa ada hubungan pendidikan ibu dengan praktik pemberian MP-ASI pada balita usia 6-24 bulan.

Dengan demikian dapat dikatakan pola pemberian makanan bagi balita sangat tergantung kepada ibu atau pengasuhnya, di mana cara pola asuh ibu sangat erat kaitannya dengan pendidikan yang ditempuh oleh seorang ibu. ${ }^{10,11}$

\section{Hubungan antara Pengetahuan lbu dengan Pola Pemberian MP-ASI pada Anak Usia 6-24 Bulan}

Pola pemberian MP-ASI yang sesuai sebagian besar pada ibu balita yang memiliki pengetahuan baik yaitu 75,0 persen, dan sebanyak 4,2 persen pada ibu balita yang memiliki pengetahuan kurang. $\mathrm{Hal}$ ini menunjukkan, bahwa semakin baik tingkat pengetahuan seseorang maka pola pemberian MP-ASI pada anak balita cenderung akan semakin baik, begitu juga sebaliknya dengan tingkat pengetahuan yang kurang, maka akan semakin kurang pula pola pemberian MP-ASI yang diberikan kepada anaknya.

Hasil penelitian ini sejalan dengan penelitian Lestari menunjukkan 51,1 persen mempunyai pengetahuan sedang tentang praktik pemberian MP-ASI dan 24,4 persen mempunyai pengetahuan kurang tentang praktik pemberian MP-ASI. ${ }^{9}$ Penelitian Yonatan dan Yusiana (2011) juga menunjukkan responden yang memiliki pengetahuan kurang sebagian besar $(52.9 \%)$ memberikan MP-ASI < 6 bulan dan responden yang memiliki pengetahuan baik sebagian besar $(66,7 \%)$ memberikan MP-ASI > 6 bulan. ${ }^{5}$ Hasil ini juga relevan dengan studi Nuraeni (2002) yang menyebutkan bahwa faktor yang paling berkontribusi terhadap pola pemberian MP-ASI adalah pengetahuan ibu $(p<0,001){ }^{10}$

\section{SIMPULAN}

Studi ini menunjukkan adanya hubungan antara pendidikan dan pengetahuan ibu balita dengan pola pemberian MP-ASI.

\section{RUJUKAN}

1. Farida B. Ayuk, Ali Khomsan, C. Meti Dwiriani. Pengantar Pangan Dan Gizi. Bogor: PenebaranSwadaya; 2004.

2. Kodrat, L. Dahsyatnya ASI dan Laktasi. Yogyakarta: Media Baca; 2010.

3. Departemen Kesehatan RI. Pedoman Pemberian Makanan Bayi dan Anak. Jakarta: Ditjen Bina Kesehatan Masyarakat ; 2007.

4. Notoatmodjo, S. Pendidikan dan perilaku kesehatan. Jakarta: RinekaCipta; 2003.

5. Kristianto, $Y$ dan Yusiana, M.A. Analisis Faktor yang Mempengaruhi Perilaku lbu dan Pemberian MP-ASI Terlalu Dini di Posyandu Mawar I di desa Karang Rejo, Kediri. Jurnal Penelitian Akademi Kesehatan Rajekwesi Bojonegoro. 2012;5(3).

6. Wiryo H. Gizi Masyarakat. Mataram: Mataram University Press; 2004.

7. Dinkes Propinsi NTB. Hasil Pemantauan Status Gizi Balita Propinsi Nusa Tenggara Barat. Mataram: Dinkes NTB; 2010.

8. Notoatmodjo, Sukidjo. Metodelogi Penelitian Kesehatan. Jakarta: Rineka Cipta; 2010.

9. Lestari, Nining. 2004. Makanan Sehat Balita. C2004. Diakses pada tanggal 16 oktober 201. Available from: http://resto.co.id/sht/makanan sehat balita/htm

10. Nuraeni. Hubungan Karakteristik Ibu, Dukungan Keluarga dan Pendidikan Kesehatan dengan Perilaku Pemberian ASI dan MP-ASI di Desa waru Jaya Kecamatan Parung Kabupaten Bogor tahun 2002. c2002. Thesis. Diakses tanggal 26 Januari 2012.

Available from:http://lontar.ui.ac.id/opac/themes/libri2.

11. Swastini, P.M. Hubungan Pengetahuan, Sikap Ibu dengan Praktik Pemberian Makanan Pendamping ASI (MP-ASI) pada Balita Usia 6-24 bulan di Kelurahan Warakas Kecamatan Tanjung Priok. c2010.Diakses 26 Oktober 2012. Available from:http://library.upnvi.ac.id/ 
12. Gibney, M.J, Margetts BM, Kearney JM, Arab L. Gizi Kesehatan Masyarakat. Jakarta: EGC; 2008 